\title{
Overcriminalization dalam Perundang-Undangan di Indonesia
}

\author{
Mahrus Ali \\ Fakultas Hukum Universitas Islam Indonesia \\ Mahasiswa Program Doktor Ilmu Hukum Universitas Diponegoro \\ Jl. Tamansiswa 158 Yogyakarta, 55151 \\ mahrus_ali@uii.ac.id
}

Received: 26 Nopember 2018; Accepted: 12 Desember 2018; Published: 17 Januari 2019

DOI: 10.20885/iustum.vol25.iss3.art2

\begin{abstract}
Criminalization in legislation tends to increase, and most of it deals with administrative violations with the potential to cause over-criminalization. This study aims to analyze the concept of over-criminalization and its various forms in criminal legislation. As normative legal research, this study uses a conceptual and statutory approach. The results show that over-criminalization is generally conceptualized in relation to criminalization. The forms also include re-criminalization of an act having been banned by other laws, formulation of offenses without sufficient error requirements, criminalization of impeccable deeds, formulation of offenses without fulfilling the principle of lex certa, criminalization of pure administrative violations, and criminal penalties incomparable to the seriousness of the offenses. The forms of overcriminalization in legislation are obvious in different articles in Law on Plantations, Law Environmental Protection, and Management, and Law on Mineral and Coal Mining.
\end{abstract}

Keywords: Over-criminalization; criminal law; legislation

\section{Abstrak}

Kriminalisasi dalam perundang-undangan cenderung meningkat dan kebanyakan terkait pelanggaranpelanggaran administrasi, sehingga berpotensi menimbulkan overcriminalization. Penelitian ini bertujuan untuk menganalisis konsep overcriminalization dan ragam bentuknya dalam perundangundangan pidana. Sebagai penelitian hukum normatif, penelitian ini menggunakan pendekatan konseptual dan perundang-undangan. Hasil penelitian ini menyimpulkan bahwa overcriminalization pada umumnya dikonsepsikan dalam kaitannya dengan kriminalisasi. Bentuk-bentuknya pun beragam meliputi rekriminalisasi suatu perbuatan yang telah dilarang oleh undang-undang yang lain, perumusan delik tanpa persyaratan kesalahan pelanggar yang memadai, kriminalisasi terhadap perbuatan perbuatan yang tidak tercela, perumusan delik yang tidak memenuhi prinsip lex certa, kriminalisasi terhadap pelanggaran administratif murni, dan ancaman pidana tidak sebanding dengan seriusitas delik. Bentuk-bentuk overcriminalization dalam perundang-undangan terlihat dalam beberapa pasal dalam UU Perkebunan, UU PPLH, dan UU Minerba.

Kata-kata Kunci: Overcriminalization; hukum pidana; perundang-undangan 


\section{Pendahuluan}

Perbuatan-perbuatan yang dikriminalisasi ${ }^{1}$ dalam undang-undang di luar KUHP, dari 1985 hingga 2014 memperlihatkan kecenderungan semakin kuatnya kontrol negara terhadap aktifitas dan kebebasan sipil warga negara. Penelitian Barda Nawawi Arief mengungkap, bahwa terdapat sebanyak 29 undang-undang yang memuat ketentuan pidana dari 1985 hingga 1995. ${ }^{2}$ Hasil penelitian Anugerah Rizki Akbari, menunjukkan bahwa dalam kurun waktu 1998 hingga 2014, dari 392 undang-undang yang dibentuk dan disahkan legislator, 154 di antaranya memuat ketentuan pidana. ${ }^{3}$ Ini artinya, terdapat hampir 40\% undang-undang yang dibentuk DPR yang memuat ketentuan pidana. Apabila ditotal, dari 1985 hingga 2014 terdapat 183 undang-undang yang memuat ketentuan pidana. ${ }^{4}$

Undang-undang yang memuat ketentuan pidana kebanyakan merupakan undang-undang pidana administrasi (hukum pidana administrasi). ${ }^{5}$ Hukum pidana administrasi dalam kepustakaan hukum pidana disebut dengan istilah 'administrative penal law', 'public welfare offenses', 'regulatory offenses', atau 'ordeningstrafrecht'. Istilah ini mengacu kepada pelanggaran-pelanggaran administrasi yang diancam dengan sanksi pidana. ${ }^{6}$ Keberadaan sanksi pidana dicantumkan untuk memperkuat sanksi administratif.7 Oleh karenanya, sanksi pidana berperan sebagai mercenary-sanction, ${ }^{8}$ dalam arti hanya bersifat menunjang penegakan norma yang ada di bidang hukum lainnya. ${ }^{9}$

\footnotetext{
${ }^{1}$ Kriminalisasi dalama penelitian ini didefinisikan sebagai suatu kebijakan dalam menetapkan suatu perbuatan yang semula bukan tindak pidana (tidak dipidana) menjadi suatu tindak pidana (perbuatan yang dapat dipidana) disertai ancaman sanksi pidana. hlm. 11

2 Barda Nawawi Arief, Kapita Selekta Hukum Pidana, Cetk. Ketiga, PT. Citra Aditya Bakti, Bandung, 2013,

3 Anugerah Rizki Akbari, Potret Kriminalisasi Pasca Reformasi dan Urgensi Reklasifikasi Tindak Pidana di Indonesia, Institute for Criminal Justice Reform, Jakarta, 2015, hlm. 10

4 Angka 183 undang-undang ini merupakan penjumlahan dari 29 undang-undang yang memuat ketentuan pidana dari 1985 hingga 1995 dan 154 undang-undang yang memuat ketentuan pidana dari 1998 hingga 2014.

${ }^{5}$ Supriadi, "Penetapan Tindak Pidana Sebagai Kejahatan dan Pelanggaran dalam undang-undang Pidana Khusus", Mimbar Hukum, Vol 27, 3, 2015, hlm. 394

${ }^{6}$ Barda Nawawi Arief, Kapita Selekta..., Op. Cit., hlm. 10. Indrianto Seno Adji, Administratif Penal Law: Ke Arah Konstruksi Pidana Limitatif, Makalah Disampaikan pada Pelatihan Hukum dan Kriminologi oleh MAHUPIKI Bekerjasama dengan Fakultas Hukum UGM, Yogyakarta, 23-27 Februari 2014, hlm. 6 42

${ }^{7}$ Muladi, Kapita Selekta Sistem Peradilan Pidana, Badan Penerbit Universitas Dipenogoro, Semarang, 1995, hlm.

${ }^{8}$ Ibid., hlm. 39

${ }^{9}$ Muladi, 'Proyeksi Hukum Pidana Materiil Indonesia di Masa Mendatang', Pidato Pengukuban Guru Besar Ilmu Hukum Pidana, Fakultas Hukum Universitas Diponegoro, Semarang, 24 Februari, 1990, hlm. 7
} 
Data tentang banyaknya undang-undang yang memuat ketentuan pidana terkait masalah di luar hukum pidana setidaknya berimplikasi kepada dua hal. Pertama, ada perubahan cara pandang di dalam mengatasi problem sosial, dari yang semula mendayagunakan instrumen hukum perdata/administrasi ke instrumen hukum pidana. Hukum pidana tidak lagi ditempatkan sebagai sarana terakhir (the last resort/ ultimum remedium) dalam menanggulangi kejahatan, ${ }^{10}$ melainkan sebagai premum remedium. Kedua, proses kriminalisasi yang berlangsung secara terus menerus tanpa didasarkan pada penilaian yang teruji dan tanpa suatu evaluasi mengenai pengaruhnya terhadap keseluruhan sistem juga mengakibatkan timbulnya krisis kelebihan kriminalisasi (the crisis of overcriminalization), yaitu banyak atau melimpahnya jumlah kejahatan dan perbuatan-perbuatan yang dikriminalisasi. ${ }^{11}$ Oleh karena itu, perlu diteliti konsep overcriminalization dan ragam bentuknya dalam perundang-undangan di Indonesia.

\section{Rumusan Masalah}

Berdasarkan di atas, rumusan masalah dalam penelitian ini sebagai berikut; pertama, bagaimana perkembangan konsep overcriminalization dalam hukum pidana?; dan kedua, bagaimana ragam bentuk overcriminalization dalam perundangundangan pidana?

\section{Tujuan Penelitian}

Penelitian ini bertujuan untuk mengetahui dan menganalisis; pertama, perkembangan konsep overcriminalization dalam hukum pidana; dan kedua, ragam bentuknya dalam perundang-undangan pidana.

\section{Metode Penelitian}

Penelitian ini merupakan penelitian hukum normatif karena yang dikaji adalah konsep overcriminalization dan bentuk-bentuknya dalam perundangundangan di Indonesia. Pendekatan yang digunakan adalah pendekatan

${ }^{10}$ Nils Jareborg, "Criminalization as Last Resort (Ultima Ratio)", Ohio State Journal of Criminal Law, 2005, hlm.

${ }^{11}$ M. Sherif Bassiouni, Substantive Criminal Law, Charles Thomas Publisher, Springfield, Illionis, USA, 1978 sebagaimana dikutip oleh Barda Nawawi Arief, Kebijakan Legislatif dalam Penanggulangan Kejabatan dengan Pidana Penjara, Cetk Ketiga, Badan Penerbit Universitas Diponegoro, Semarang, 2000, hlm 38; Barda Nawawi Arief, Bunga Rampai Kebijakan Hukum Pidana,Cetk. Ketiga, Edisi Revisi, PT. Citra Aditya Bakti, Bandung, 2005, hlm. 33; Muladi dan Barda Nawawi Arief, Teori-teori dan Kebijakan Hukum Pidana, Alumni, Bandung, 1998, hlm. 163 
konseptual dan perundang-undangan. ${ }^{12}$ Pendekatan konseptual mengacu pendapat ahli hukum pidana tentang konsep dan ruang lingkup overcriminalization, sedangkan pendekatan perundang-undangan mengkaji bentuk-bentuk overcriminalization dalam rumusan delik dan ancaman pidana dalam perundangundangan. Bahan hukum yang digunakan yaitu bahan hukum primer terdiri dari Undang-Undang Nomor 39 Tahun 2014, Undang-Undang Nomor 32 Tahun 2009, dan Undang-Undang Nomor 4 Tahun 2009, dan bahan hukum sekunder. Bahan hukum yang dikumpullkan melalui studi literatur dianalisis secara deskriptif kualitatif. Terdapat tiga alur kegiatan dalam analisis kualitatif, yaitu reduksi bahan hukum, penyajian bahan hukum, dan penarikan kesimpulan. Reduksi bahan hukum terkait dua hal, yaitu penyederhanaan konsep overcriminalization dalam hukum pidana, dan pembacaan rumusan delik dan ancaman pidananya dalam suatu undang-undang.

\section{Hasil Penelitian dan Pembahasan}

\section{Perkembangan Konsep Ovekriminalisasi}

Sanford H. Kadish merupakan ahli pertama yang membicarakan tentang overcriminalization, dalam artikel berjudul 'the crisis of overcriminalization' yang ditulis pada 1968. Menurut Kadish, dewasa ini hukum pidana telah memperluas jangkauan sanksi pidana kepada jenis-jenis perilaku yang sangat berbeda, suatu perilaku yang tidak menimbulkan kerugian yang serius, atau kejahatan yang bahkan tidak menimbulkan kerugian apapun. ${ }^{13}$ Overcriminalization oleh Kadish diartikan sebagai penggunaan hukum pidana untuk mewujudkan tujuan-tujuan kebijakan publik yang sama sekali tidak layak/tidak dibenarkan untuk dilarang. ${ }^{14}$ Perbuatan-perbuatan yang netral secara moral tidak layak dikriminalisasi, seperti hubungan seksual yang dilakukan secara suka sama suka. Menurut peneliti, perbuatan-perbuatan yang seperti apa yang dianggap sebagai perbuatan yang

\footnotetext{
${ }^{12}$ Johny Ibrahim, Teori dan Metodologi Penelitian Hukum Normatif, Bayu Media Publishing, Malang, 2006, hlm. 320

13 '...Criminal law typically has extended the criminal sanction well beyond these fundamental offenses to include very different kinds of behavior, kinds which threaten far less serious harms, or else highly intangible ones about which there is no genuine consensus, or even no harms at all'. Sanford H. Kadish, "The Crisis of Overcriminalization", American Criminal Law, 1968, hlm. 17

14 Michal Buchhandler-Raphael, “Overcriminalizing Speech”, Cardozo Law Review, 2015, hlm. 1679
} 
netral secara moral berbeda antara satu negara dengan negara yang lain dan bergantung kepada falsafah yang dianutnya. Bagi Indonesia, pemikiran Kadish tersebut tidak selamanya bisa diikuti sejak Pancasila disepakati oleh pendiri bangsa sebagai cita hukum (rechtsidee) dan pandangan hidup bangsa sehingga nilai-nilai yang terkandung di dalamnya harus menjadi pedoman/pijakan/sumber nilai dalam mengkriminalisasi suatu perbuatan. ${ }^{15}$

Barda Nawawi Arief mengartikan overcriminalization sebagai banyak atau melimpahnya jumlah kejahatan dan perbuatan-perbuatan yang dikriminalisasi. Overcriminalization timbul bila proses kriminalisasi yang berlangsung secara terus menerus tanpa didasarkan pada penilaian yang teruji dan tanpa suatu evaluasi mengenai pengaruhnya terhadap keseluruhan sistem. ${ }^{16}$ Kip Schlegel, David Eitle, dan Steven Gunkel menganggap bahwa masalah overcriminalization terkait dua hal. ${ }^{17}$ Pertama, konsep overcriminalization merefleksikan suatu perhatian yang lebih luas dari peranan sanksi pidana dan persepsi yang digunakan tentang perilaku penjahat. Pertanyaan yang muncul terkait yang pertama ini, adalah perilakuperilaku yang seperti apa yang dianggap sebagai kejahatan. Pertanyaan tentang sampai sejauh mana sanksi pidana diterapkan tidak lebih penting dari pertanyaan tentang persyaratan-persyaratan apa saja yang harus dipenuhi agar sanksi pidana dapat diterapkan. Overcriminalization, dengan demikian, merepresentasikan pengenaan label penjahat atas perilaku yang sebenarnya tidak memenuhi kriteria label tersebut.

Kedua, konsep overcriminalization juga memberikan perhatian kepada seringnya sanksi pidana diterapkan kepada suatu perbuatan seketika dinyatakan sebagai perbuatan terlarang. Pertanyaan terkait hal ini, adalah seberapa sering sanksi pidana diancamkan dan seberapa berat sanksi pidana itu dijatuhkan kepada

${ }^{15}$ Nilai-nilai yang terkandung dalam Pancasila adalah nilai ketuhanan, nilai kemanusiaan, nilai persatuan, nilai kerakyatan, dan nilai keadilan sosial. Barda Nawawi Arief meringkas kelima nilai tersebut menjadi nilai ketuhanan (moral religius), nilai kemanusiaan (nilai humanistik), dan nilai kemasyarakatan (nasionalistik, demokratis, dan keadilan sosial). Barda Nawawi Arief, Pembangunan Sistem Hukum Nasional (Indonesia), Cetk. Kedua, Pustaka Magister, Semarang, 2015, hlm. 31

${ }^{16}$ Barda Nawawi Arief, Kebijakan Legislatif dalam Penanggulangan Kejahatan dengan Pidana Penjara, Cetk. Ketiga, Badan Penerbit, Universitas Diponegoro, Semarang, 2000, hlm. 38; Barda Nawawi Arief, Bunga Rampai Kebijakan Hukum Pidana, Cetk. Ketiga, Edisi Revisi, PT. Citra Aditya Bakti, Bandung, 2005, hlm. 33

${ }^{17}$ Kip Schlegel, David Eitle, Steven Gunkel, “Are White-Collar Crimes Overcriminalized? Some Evidence on the Use of Criminal Sanctions against Securities Violators”, Western State University Law Review, 2000-2001, hlm. 120-121 
orang yang melakukan suatu kejahatan. Overcriminalization merepresentasikan pengenaan sanksi pidana yang lebih sering daripada respon kontrol sosial lainnya yang tersedia yang lebih pantas dan pengenaan sanksi pidana yang tidak sesuai dengan tujuannya.

Ellen S. Podgor mengartikan overcriminalization, sebagai banyaknya perbuatan-perbuatan yang dikriminalisasi tanpa dasar pembenar dan penggunaan suatu ketentuan pidana dalam undang-undang melalui diskresi penuntut umum. Undang-undang memberikan kewenangan diskresi yang besar kepada penuntut umum untuk menentukan mana perbuatan yang sesuai dengan rumusan delik.18 Konsep ini masih bersifat umum karena belum menggambarkan bentuk-bentuk perbuatan yang menimbulkan overcriminalization. Selain itu, konsep tersebut mencampuraduk antara overcriminalization yang merupakan dampak dari proses kriminalisasi tanpa evaluasi dan irasional dengan penegakan hukum yang berlebihan berupa pemberian kewenangan kepada penuntut umum untuk menentukan mana perbuatan-perbuatan yang sesuai dengan rumusan delik.

Erik Luna mengemukakan, bahwa overcriminalization tidak hanya terkait dengan begitu banyaknya perbuatan yang dilarang, tapi juga termasuk masalah berikut; apakah yang harus didenominasikan sebagai kejahatan dan kapan ia ditegakkan; dan apa yang seharusnya dijadikan batasan-batasan pidana dan sanksi pidana yang tepat dalam kasus-kasus yang spesifik. Overcriminalization, dengan demikian, merupakan penyalahgunaan kekuasaan tertinggi sistem peradilan pidana, yaitu implementasi kejahatan atau pengenaan sanksi pidana tanpa dasar pembenar. Overcriminalization terdiri atas; (1) tindak pidana-tindak pidana yang tidak dapat dipertahankan lagi karena tidak memenuhi kriteria untuk dikategorikan sebagai perbuatan terlarang; (2) perundang-undangan pidana yang berlebihan; (3) ancaman sanksi pidana yang tidak proporsional; dan (4) penegakan hukum yang eksesif terhadap pelanggaran-pelanggaran ringan. ${ }^{19}$

Sara Sun Beale mengkonsepsikan overcriminalization dalam kaitannya dengan penegakan hukum yang berlebihan (overenforcement) oleh aparat penegak hukum.

${ }^{18}$ Ellen S. Podgor, "Overcriminalization: The Politics of Crime”, American University Law Review, 54, 2005, hlm. 542-543

${ }^{19}$ Erik Luna, “The Overcriminalization Phenomenon”, American University Law Review, 2005, hlm. 713-717 
Menurutnya, secara umum bentuk-bentuk overcriminalization meliputi; a) pemberian kewenangan diskresi yang tidak terkontrol kepada penegak hukum; b) disparitas pidana terhadap beberapa pelaku yang melakukan kejahatan yang sama; dan c) penyalahgunaan kekuasaan oleh penegak hukum. ${ }^{20}$ Sementara itu, Andrew Ashworth mengatakan bahwa overcriminalization terjadi manakala hukum pidana bekerja melebihi tiga fungsi utamanya, yakni fungsi deklaratif, fungsi preventif dan fungsi regulatif. ${ }^{21}$ Dalam kaitannya dengan fungsi deklaratif, overcriminalization timbul ketika pidana dijatuhkan tanpa adanya kesalahan atau tindak pidana yang ringan dikategorikan sebagai tindak pidana yang serius. Dalam konteks fungsi preventif, overcriminalization timbul ketika perbuatan-perbuatan yang dilarang tidak berbahaya atau kemungkinan timbulnya bahaya yang dituju dari dilarangnya suatu perbuatan masih jauh. Dalam kaitannya dengan fungsi regulatif, overcriminalization timbul ketika perbuatan yang dikriminalisasi merupakan pelanggaran administratif atau perdata, atau sanksi perdata/administratif lebih efektif diberdayakan. ${ }^{22}$

Samuel W. Buell mengartikan overcriminalization sebagai '...producing an overbroad criminal prohibition by saying the law was designed to cover conduct for which there is not a good case for sanction'.23 Jadi, ruang lingkup perbuatan yang dikriminalisasi yang terlalu luas merupakan salah satu bentuk overcriminalization. Adapun Douglas Husak mengartikan overcriminalization sebagai '...too much punishment, too much crimes...' ${ }^{24}$ Menurut Husak, delik dalam hukum pidana secara umum dibagi menjadi core crime dan periphery offenses. ${ }^{25}$ Core crimes adalah kejahatan-kejahatan yang dari sifat dasarnya merupakan perbuatan yang jahat seperti pembunuhan, pencurian, perkosaan, dan penipuan, sedangkan periphery

20 Sara Sun Beale, "The Many Faces of Overcriminalization: From Morals and Mattress Tags to Overfederalization", American University Law Review, 54, 2005, hlm. 749

${ }^{21}$ The declaratory function is the declaration of forms of wrongdoing that are serious enough to justify the public censure inherent in conviction and punishment. The preventive function is the declaration of forms of conduct or omission that are probibited on the basis of their propensity to lead to significant risk or danger to an interest protected by the law, and which justify the censure inherent in conviction and punishment. The regulatory function is the reinforcement of regulation through the declaration of forms of conduct, often without requiring proof of fault, which amount to non-compliance with a regulatory scheme. Andrew Ashworth, "Conception of Overcriminalization", Ohio State Journal of Criminal Law, 5, 2008, hlm. 407 dan 424

${ }^{22}$ Ibid., hlm. 424

${ }^{23}$ Samuel W. Buell, “The Upside of Overbreadth”, New York University Law Review, 83, 2008, hlm. 1497

${ }^{24}$ Douglas Husak, Overcriminalization The Limits of the Criminal Law, Oxford Unversity Press, New York, 2008, hlm. 4; Todd Haugh, “Overcriminalization's New Harm Paradigm”, V anderbilt Law Review, 68, 2015, hlm. 1197

25 Peter Ramsay, “Overcriminalization as Vulnerable Citizenship”, New Criminal Law Review, 13, 2010, hlm. 263-264 
offenses adalah suatu tindak pidana yang berasal dari bidang non hukum pidana. Perbuatan-perbuatan tersebut awalnya merupakan pelanggaran administrasi atau perdata, tapi kemudian dilarang dan diancam dengan sanksi pidana. Husak menyebut pelanggaran ini dengan istilah crimes outside the core. ${ }^{26}$

Menurut Husak, bentuk-bentuk overcriminalization meliputi; a) overlapping crimes; b) offenses of risk-prevention; dan c) ancillary offenses. Tumpang tindih kejahatan (overlapping crimes) diartikan sebagai rekriminalisasi suatu perbuatan yang telah dilarang oleh undang-undang yang lain, atau di dalam satu undangundang terdapat dua delik yang memiliki substansi yang sama. ${ }^{27}$ Douglas Husak mengartikan overlapping crimes sebagai '...by criminalizing the same conduct over and over again...'.28 Offenses of risk prevention adalah delik yang masih dalam taraf permulaan karena tidak semua hal menyebabkan kerugian. Hal yang dilarang bukanlah kerugian, melainkan kemungkinan terjadinya kerugian. Perbuatan tersebut dilarang karena ada kemungkinan menimbulkan kerugian, sekalipun kemungkinan tidak perlu dibuktikan ketika tindak pidana terjadi. Contoh delik dalam kategori ini adalah larangan menggunakan telpon genggam saat mengemudikan kendaraan. Perbuatan ini dilarang karena dikhawatirkan akan menyebabkan kecelakaan lalu lintas. ${ }^{29}$

Ancillary offenses adalah kejahatan 'tambahan' atas kejahatan utama yang telah dilakukan oleh seseorang. ${ }^{30}$ Ada dua jenis ancillary offenses, yaitu derivatice crimes dan enforcement and information gathering offenses. Contoh jenis kejahatan pertama adalah seseorang yang seharusnya dikenakan satu dakwaan atas perampokan sebuah bank, tapi kemudian orang itu mendapatkan dakwaan kedua berupa menyimpan uang tersebut ke dalam rekening bank miliknya. Menyimpan uang di bank merupakan aktivitas komersial biasa, tapi dijadikan sebagai kejahatan berupa 'pengetahuan terdakwa dan fakta bahwa uang tersebut berasal dari hasil kejahatan'. Jenis kejahatan yang kedua adalah kejahatan yang dilakukan pada saat

\footnotetext{
${ }^{26}$ Douglas Husak, "Crimes Outside the Core", Tulsa Law Review, 2004, hlm.. 756

27 Stephen F. Smith, "Overcoming Overcriminalization”, Journal of Criminal Law and Criminology, 102, 2012, hlm. 539

${ }^{28}$ Douglas Husak, Overcriminalization..., Op. Cit., hlm. 36

${ }^{29}$ Ibid., hlm. 38

${ }^{30}$ Ibid., hlm. 40
} 
proses penyidikan suatu perkara pidana terhadap kejahatan pokok atau pengabaian untuk memberikan informasi penting yang akan menuntut perkara tersebut. Sebagai contoh, bank yang mengabaikan transaksi yang mencurigakan. Kejahatan jenis ini meningkat seiring dengan terbitnya beberapa undang-undang yang mengatur mengenai pengabaian untuk melaporkan adanya kejahatan kekerasan terhadap anak dan sebagainya. Dalam undang-undang tersebut, telah ditentukan 'siapa yang harus melapor', 'apa' yang harus dilaporkan, serta 'kapan' dan 'kepada siapa' laporan itu disampaikan. ${ }^{31}$

Menurut peneliti, tiga bentuk delik yang menimbulkan overcriminalization yang dikemukakan Husak tidak semuanya bisa diikuti dalam konteks Indonesia, terutama offenses of risk prevention dan ancillary offenses. Offenses of risk prevention hanya dapat disebut menimbulkan overcriminalization bila bahaya yang hendak dicegah dari dilarangnya suatu perbuatan ternyata tidak berbahaya atau masih jauh untuk terjadi, sedangkan untuk ancillary offenses khusunya enforcement and information gathering offences bertentangan dengan Pasal 5 Undang-Undang Nomor 8 Tahun 2010 tentang Pencegahan dan Pemberantasan Tindak Pidana Pencucian Uang, kecuali pihak pelapor (pihak bank) melaksanakan kewajiban pelaporan terkait transaksi keuangan yang mencurigakan. ${ }^{32}$

Darryl K. Brown mengartikan overcriminalization dalam kaitannya dengan kebijakan kriminalisasi. Kebijakan kriminalisasi yang dilakukan secara tidak hatihati dan tidak didasarkan argumen yang rasional berpotensi menimbulkan overcriminalization. Menurut Brown, ada tiga bentuk delik yang menimbulkan overcriminalization. Pertama, criminalization of conduct that few people think is morally wrong, or for which there is no persuasive argument of blameworthiness. Perbuatanperbuatan yang hendak dikriminalisasi merupakan perbuatan yang oleh masyarakat luas dianggap sebagai perbuatan yang bertentangan dengan moral. Overcriminalization timbul bila pembentuk undang-undang mengkriminalisasi

${ }^{31}$ Ibid., hlm. 41

32 Pasal 5 ayat (1) UU TTPU menyatakan bahwa 'setiap Orang yang menerima atau menguasai penempatan, pentransferan, pembayaran, hibah, sumbangan, penitipan, penukaran, atau menggunakan Harta Kekayaan yang diketahuinya atau patut diduganya merupakan hasil tindak pidana sebagaimana dimaksud dalam Pasal 2 ayat (1) dipidana dengan pidana penjara paling lama 5 (lima) tahun dan denda paling banyak Rp 1.000.000.000,00 (satu miliar rupiah)'. Pasal 5 ayat (2) berbunyi, 'ketentuan sebagaimana dimaksud pada ayat (1) tidak berlaku bagi Pihak Pelapor yang melaksanakan kewajiban pelaporan sebagaimana diatur dalam Undang- Undang ini. 
perbuatan yang dianggap tercela secara moral hanya oleh sebagian kecil masyarakat. Kedua, excessive punishment attached to uncontroversial criminal statutes. Jadi, overcriminalization timbul bila pidana yang berat (berlebihan) diancamkan terhadap pelanggaran biasa. Ketiga, redundant criminalization-statutes that prohibit conduct that is already criminalized, or largely so, by other statutes. Ia timbul bila ada suatu perbuatan yang dikriminalisasi padahal telah dilarang dan diancam dengan sanksi pidana di dalam undang-undang yang lain. ${ }^{33}$ Bentuk ketiga overcriminalization ini lazim dikenal dengan overlapping crimes.

Roger A. Fairfax, Jr mengatakan bahwa setidaknya ada 5 bentuk delik yang menimbulkan overcriminalization. ${ }^{34}$ Pertama, overfederalization, yaitu alokasi yang tidak tepat atas kedaulatan otoritas penegakan hukum dan prioritas penanganan perkara antara pemerintah federal dengan pemerintah negara bagian. Konsep overfederalization tidak dikenal sistem hukum Indonesia karena Indonesia merupakan negara kesatuan yang terdiri atas pemerintah pusat dan pemerintah daerah. Sekalipun pemerintah daerah diberikan kewenangan untuk membuat Peraturan Daerah yang salah satunya berisi larangan suatu perbuatan yang diancam dengan sanksi pidana, tapi hal itu terbatas pada pelanggaran peraturan daerah dan ruang lingkupnya hanya pada daerah itu. Kewenangan untuk mengkriminalisasi suatu perbuatan yang berlaku untuk seluruh wilayah kesatuan Negara Republik Indonesia dimiliki oleh DPR bersama Presiden. Kedua, tidak tepatnya kriminalisasi terhadap perbuatan-perbuatan yang tidak tercela atau perbuatan yang lebih pantas diserahkan kepada moralitas individu. Ketiga, kriminalisasi terhadap perbuatan tanpa persyaratan kesalahan pelaku. Keempat, kriminalisasi terhadap suata perbuatan yang telah dilarang di dalam undangundang yang lain. Kelima, ancaman pidana yang berlebihan dikaitkan dengan seriusitas delik.

Konsep yang berbeda mengenai overcriminalization dikemukakan oleh Stephen F. Smith. Menurutnya, selama ini overcriminalization hanya dipandang dari

\footnotetext{
${ }^{33}$ Darryl K. Brown, "Prosecutors and Overcriminalization: Thoughts on Political Dynamics and a Doctrinal Response", Ohio State Journal of Criminal Law, 6, 2009, hlm. 461-463

34 Roger A. Fairfax, Jr., "From "Overcriminalization" to "Smart on Crime": American Criminal Justice Reform-Legacy and Prospects", Journal of Law, Economics \& Policy, 7, 2011, hlm. 608-609
} 
sudut konvensional. Smith mendefinisikan overcriminalization sebagai '....undermining of the effort "to provide just and proportional punishments for offenses...".35 Oleh karena itu, overcriminalization semestinya dilihat dari dua sisi, yaitu kuantitatif dan kualitatif. Pertama berupa penggunaan dua atau lebih undang-undang pidana terhadap satu tindak pidana dan tumpang tindih kejahatan (overlapping crimes), yaitu rekriminalisasi suatu perbuatan yang telah dilarang oleh undang-undang yang lain. Kedua antara lain; a) tidak jelasnya pengertian atau batasan mengenai suatu perbuatan yang dilarang; b) tidak atau kurang dicantumkannya persyaratan kesalahan dalam suatu undang-undang pidana; c) perluasan atau masuknya hukum pidana terhadap area hukum perdata atau hukum administrasi negara; d) pengaturan ancaman pidana minimum khusus yang tidak ada hubungannya dengan pelanggaran atau kerugian yang ditimbulkan; e) beratnya ancaman pidana yang tidak sesuai dengan pelanggaran atau kerugian yang ditimbulkan (disproportionate punishment). ${ }^{36}$

Lucian E. Dervan mengkonsepsikan overcriminalization dalam kaitannya dengan kejahatan kerah putih (white collar crime). Menurutnya, ada dua delik dalam kaitannya dengan white collar crime yang menimbulkan overcriminalization, yaitu;

a) '...increasing the maximum criminal penalties for white collar offenses in an effort to punish financial criminals more harshly while simultaneously deterring others; dan

b) '...to create vague and overlapping criminal provisions in areas already criminalized in an effort to expand the tools available to prosecutors, increase the number of financial criminals prosecuted each year, and deter potential offenders...'.

Jadi, bentuk overcriminalization berupa pemberantan ancaman pidana maksimum bagi delik yang berkaitan dengan kejahatan kerah putih, rumusan delik yang samar-samar, dan tumpang tindih delik.37 Sementara itu, Paul J. Larkin Jr. Merumuskan tiga bentuk delik yang menimbulkan overcriminalization, yaitu rekriminalisasi terhadap delik yang sudah dilarang oleh undang-undang yang lain, pemberantan ancaman pidana tanpa dasar pembenar, penggunaan hukum pidana yang berlebihan sebagai instrumen pengaturan, dalam arti kriminalisasi terhadap

\footnotetext{
35 Stephen F. Smith, Overcoming..., Op. Cit., hlm. 540

36 Ibid., hlm. 537-539

${ }^{37}$ Lucian E. Dervan, "White Collar Overcriminalization: Deterrence, Plea Bargaining, and the Loss of Innocence”, Kentucky Law Journal, 2012-2013, hlm. 723-724
} 
pelanggaran-pelanggaran administratif, dan kriminalisasi terhadap perbuatan yang secara tradisional tidak tercela. ${ }^{38}$

Menurut Gregory Jones, overcriminalization seringkali muncul manakala; a) perbuatan yang dikriminalisasi tidak jelas definisi atau batasannya; b) pengundangan undang-undang pidana tanpa disertai persyaratan kesalahan yang memadai; c) pengenaan pertanggungjawaban pidana pengganti atas tindak pidana yang dilakukan oleh orang lain tanpa disertai bukti yang memadai mengenai kesengajaan atau kelalaian orang tersebut; d) perluasan hukum pidana ke dalam wilayah hukum yang secara tradisional merupakan wilayah hukum perdata atau hukum administrasi negara; e) perumusana ancaman pidana minimum khusus yang seringkali tidak ada kaitannya dengan ketercelaan atau kerugian yang mendasari suatu tindak pidana; dan f) duplikasi atau tumpang tindih perundangundangan pidana. ${ }^{39}$ Todd Haugh mengkaitkan overcriminalization dengan melimpahnya perbuatan yang dikriminalisasi dan tumpang tindih delik disertai ancaman pidana yang berat terhadap perbuatan yang seharusnya masuk dalam ruang lingkup pelanggaran perdata atau administrasi. ${ }^{40}$

Michael Pierce mengartikan overcriminalization sebagai overlapping statutes, excessive punishments, and harsh "enforcement of petty violations". ${ }^{41}$ Jadi, bentukbentuk overcriminalization berupa tumpah tindih delik, pidana yang sangat berat tanpa disertai alasan yang memadai, dan penegakan hukum yang sangat keras terhadap pelanggaran-pelanggaran ringan. Adapun Michal Buchhandler-Raphael merumuskan overcriminalization dalam lima bentuk, yaitu; a) federalization of crimes, yaitu sangat banyaknya perbuatan-perbuatan yang dikriminalisasi dalam undangundang federal; b) overlapping crimes, yaitu rekriminalisasi perbuatan yang telah dilarang oleh undang-undang yang lain; c) endangerment offenses, yaitu tujuan dilarangnya suatu perbuatan adalah mencegah timbulnya bahaya (kerugian),

\footnotetext{
${ }^{38}$ Paul J. Larkin Jr., "A Mistake of Law Defense as a Remedy for Overcriminalization”, Criminal Justice, 28, 2013, hlm. 11-13 943

${ }^{39}$ Gregory Jones, “Over-Criminalization and the Need for a Crime Paradigm”, Rutgers Law Review, 2014, hlm.

${ }^{40}$ Todd Haugh, "Sox on Fish: A New Harm of Overcriminalization", Northwestern University Law Review, 109, 2015, hlm. 836

${ }^{41}$ Michael Pierce, “The Court and Overcriminalization", Stanford Law Review Online, 68, 2015, hlm. 50
} 
sekalipun kerugian itu tidak perlu dibuktikan; d) ancillary offenses, yaitu delik yang berfungsi membantu penuntutan terhadap delik asal. ${ }^{42}$

Berdasarkan uraian di atas, para ahli mengkonsepsikan overcriminalization dalam arti yang beragam. Meskipun demikian, secara umum konsep overcriminalization yang dikemukakan oleh mereka mengacu kepada dua hal, yaitu overcriminalization dalam kaitannya dengan kriminalisasi (kebijakan formulasi/penegakan hukum in abstracto) dan overcriminalization dalam konteks penegakan hukum oleh aparat penegak hukum (kebijakan aplikasi/penegakan hukum in concreto). Menurut Isaac D. Buck, overcriminalization dalam konteks penegakan hukum in concreto lebih cocok disebut dengan istilah overenforcement (penegakan hukum yang berlebihan), yaitu '...when the violator of a legal rule suffers excessive harm--or more harm than is necessary for optimal deterrence--from the actual implementation of that rule'. ${ }^{33} \mathrm{Jadi}$, overenforcement tidak hanya terkait dengan bidang hukum pidana, melainkan juga bidang-bidang hukum yang lain seperti hukum perdata atau hukum administrasi negara.

Arti dan ruang lingkup overcriminalization dalam penelitian ini dibatasi pada kebijakan legislasi (kebijakan formulasi), yaitu perumusan garis-garis kebijakan sistem pidana dan pemidanaan yang sekaligus merupakan landasan legalitas bagi tahap-tahap berikutnya, yaitu tahap penerapan pidana oleh badan peradilan dan tahap pelaksanaan pidana oleh aparat pelaksana pidana..44 Overcriminalization dibatasi dalam kaitannya dengan kriminalisasi (kebijakan formulasi/penegakan hukum in abstracto). Alasannya adalah karena kriminalisasi merupakan kebijakan pada tahap formulasi untuk menentukan suatu perbuatan sebagai tindak pidana dan disertai ancaman sanksi pidana. Oleh karena kriminalisasi hanya terkait penentuan suatu perbuatai sebagai delik disertai ancaman sanksi pidana, maka overcriminalization dalam penelitian ini juga termasuk kelebihan pidana (overpenalization) berupa beratnya ancaman sanksi pidana yang tidak sepadan dengan seriusitas delik. Hal ini karena pada umumnya pelarangan terhadap perbuatan-perbuatan tertentu oleh pembentuk undang-undang diikuti dengan

42 Michal Buchhandler-Raphael, “Overcriminalizing Speech”, Cardozo Law Review, 36, 2015, hlm. 1670

${ }^{43}$ Isaac D. Buck, "Enforcement Overdose: Health Care Fraud Regulation in an Era of Overcriminalization and Overtreatment", Maryland Law Review, 74, 2015, hlm. 265-266

${ }^{44}$ Barda Nawawi Arief, Kebijakean Legislatif..., Op. Cit., hlm. 3 
ancaman sanksi pidana. Ia juga dibatasi pada hukum pidana materiil meskipun ada ahli yang memperluas overcriminalization pada hukum pidana formil. ${ }^{45}$

Bentuk-bentuk overcriminalization yang dikemukakan ahli juga beragam. Apabila disimpulkan, setidaknya ada beberapa bentuk overcriminalization. Pertama, overcriminalization dilihat dari aspek kuantitatif, yakni duplikasi atau tumpang tindih perundang-undangan pidana atau penggunaan dua atau lebih undangundang pidana terhadap satu tindak pidana dan tumpang tindih kejahatan (overlapping crimes), yaitu rekriminalisasi suatu perbuatan yang telah dilarang oleh undang-undang yang lain. Kedua, kesalahan pelanggar dimasukkan ke dalam konsep dan ruang lingkup overcriminalization. Dikatakan terjadi overcriminalization jika delik dirumuskan tanpa persyaratan kesalahan yang memadai. Ketiga, overcriminalization terjadi bila perbuatan yang dikriminalisasi merupakan perbuatan yang tidak tercela.

Keempat, overcriminalization terjadi bila ancaman pidana tidak sebanding dengan seriusitas delik, dalam arti ancaman pidana jauh lebih berat dari seriusitas delik. Kelima, overcriminalization terjadi dalam kaitannya dengan offenses of risk prevention dan ancillary offenses. Keenam, overcriminalization terjadi bila delik yang dilarang sebenarnya merupakan pelanggaran administrasi atau pelanggaran perdata. Ketujuh, overcriminalization terjadi manakala delik dirumuskan secara samar-samar sehingga tidak jelas arti dan ruang lingkupnya. Kedelapan, overcriminalization terjadi dalam kaitannya dengan penegakan hukum yang eksesif terhadap pelanggaran-pelanggaran ringan, pemberian kewenangan diskresi yang tidak terkontrol kepada penegak hukum, dan penyalahgunaan kekuasaan oleh penegak hukum. Bentuk terakhir overcriminalization ini lebih cocok disebut penegakan hukum yang berlebihan (overenforcement).

\section{Ragam Bentuk Overcriminalization dalam Perundang-undangan}

Ragam bentuk overcriminalization dalam perundangan-undang pidana meliputi; a) rekriminalisasi delik (overlapping crimes); b) rumusan delik yang tidak jelas arti dan ruang lingkupnya (lex certa); c) perbuatan yang dikriminalisasi murni

45 William J. Stuntz, "Substance, Process, and the Civil-Criminal Line", Journal of Contemporary Legal Issues, 1996, hlm. 7-19 
sebagai pelanggaran administratif; dan d) dan beratnya pidana tidak mencerminkan seriusitas delik (disproportionate sentence). Keempat bentuk overcriminalization ditemukan dalam sejumlah undang-undang pidana di luar KUHP.

Rumusan delik yang masuk dalam kategori overlapping crimes terdapat dalam Pasal 108 jo Pasal 56 ayat (1) UU Perkebunan ${ }^{46}$ dan Pasal 108 jo Pasal 69 ayat (1) huruf h UU PPLH. ${ }^{47}$ Pasal 108 UU Perkebunan berbunyi bahwa 'setiap Pelaku Usaha Perkebunan yang membuka dan/atau mengolah lahan dengan cara membakar sebagaimana dimaksud dalam Pasal 56 ayat (1)...', sedangkan rumusan Pasal 108 jo Pasal Pasal 69 ayat (1) huruf h bahwa 'setiap orang yang melakukan pembakaran lahan sebagaimana dimaksud dalam Pasal 69 ayat (1) huruf h...'.

Substansi kedua pasal di atas adalah sama-sama melarang membakar lahan. Lahan yang dimaksud lahan yang dimaksud dalam UU Perkebunan adalah lahan perkebunan, sedangkan lahan dalam UU PPLH lahan apapun termasuk lahan perkebunan.. Meskipun objek pembakaran dalam UU Perkebunan dibatasi pada lahan perkebunan, tapi substansi pasal tersebut sebenarnya sama dengan substansi dalam Pasal 108 UU PPLH. Oleh karena itu, ada satu perbuatan yang sama yang diatur di dalam dua undang-undang yang sama-sama terkait lingkungan hidup. Pengaturan delik yang demikian menimbulkan overcriminalization dalam bentuk overlapping crimes, yaitu satu perbuatan yang sama dilarang dan diatur dalam dua undang-undang yang berbeda. 48

Rumusan delik yang yang tidak memenuhi prinsip lex certa terdapat Pasal 162 jo Pasal 136 ayat (2) UU Minerba ${ }^{49}$ yang berbunyi sebagai berikut

Setiap orang yang merintangi atau mengganggu kegiatan usaha pertambangan dari pemegang IUP atau IUPIK yang telah memenuhi syarat dalam Pasal 136 ayat (2)...'.

Subyek delik dalam ketentuan pasal di atas tidak dibatasi pada pelaku usaha, tapi juga masyarakat di sekitar perusahaan tambang beroperasi termasuk masyarakat hukum adat. Perbuatan yang dilarang adalah 'merintangi atau mengganggu kegiatan

\footnotetext{
${ }^{46}$ Undang-Undang No. 39 Tahun 2014 tentang Perkebunan

${ }^{47}$ Undang-Undang No. 32 Tahun 2009 tentang Perlindungan dan Pengelolaan Lingkungan Hidup

48 Peter Ramsay, "Overcriminalization as Vulnerable Citizenship", New Criminal Law Review, 13, 2010, hlm. 264

${ }^{49}$ Undang-Undang No. 4 Tahun 2009 tentang Pertambangan Mineral dan Batubara
} 
usaha pertambangan dari pemegang IUP atau IUPIK yang telah memenuhi syarat..'. Tidak jelas apa yang dimaksud dengan perbuatan 'merintangi atau mengganggu kegiatan usaha pertambangan', karena undang-undang Pertambangan Mineral dan Batubara tidak memberikan penjelasan tentang hal itu. Dengan dalih telah memiliki IUP atau IUPK, pelaku usaha dapat melaporkan kepada polisi protes warga yang tidak setuju adanya penambangan di wilayahnya karena akan merusak lingkungan hidup dan menghilangkan mata pencaharian mereka, dengan alasan bahwa perbuatan mereka itu mengganggu atau merintangi kegiatan usaha pertambangan.

Penunjukkan Pasal 136 ayat (2) bermakna bahwa pemegang IUP atau IUPK sudah dapat melakukan aktifitas pertambangan tanpa harus menunggu masalah pertanahan selesai $100 \%$. Frase 'penyelesaian hak atas tanah dapat dilakukan secara bertahap sesuai dengan kebutuhan atas tanah oleh pemegang IUP atau IUPK' menunjukkan, bahwa masyarakat di sekitar perusahaan tambang atau pemilih tanah yang hak atas tanah tersebut dikuasi oleh pemegang IUP atau IUPK, dapat dikatakan melakukan tindak pidana jika mereka menolak perusahaan tambang beroperasi dengan dalih sengketa pertanahan belum diselesaikan. Hal ini karena tidak ada kewajiban bagi pemegang IUP atau IUPK untuk menyelesaikan hal itu $100 \%$, tapi cukup dilakukan secara bertahap. Dengan dasar bahwa mereka telah memegang izin, tindakan masyarakat tersebut sudah bisa dianggap sebagai tindak pidana meskipun tindakan mereka itu rasional. ${ }^{50}$

Perbuatan yang dikriminalisasi murni sebagai pelanggaran administratif terdapat dalam Pasal 105 UU Perkebunan yang berbunyi sebagai berikut:

'Setiap Perusahaan Perkebunan yang melakukan usaha budi daya Tanaman Perkebunan dengan luasan skala tertentu dan/atau usaha Pengolahan Hasil Perkebunan dengan kapasitas pabrik tertentu yang tidak memiliki izin Usaha Perkebunan sebagaimana dimaksud dalam Pasal 47 ayat (1)...'.

Esensi delik dalam pasal di atas adalah 'melakukan usaha budi daya Tanaman Perkebunan dengan luasan skala tertentu tidak memiliki Izin Usaha Perkebunan' dan/atau 'melakukan usaha Pengolahan Hasil Perkebunan dengan kapasitas

${ }^{50}$ Douglas N. Husak, "Reasonable Risk Creation and Overinclusive Legislation", Buffalo Criminal Law Review, 1, 1998, hlm. 604. Douglas Husak, "Social Engineering as an Infringement of the Presumption of Innocence: The Case of Corporate Criminality", Criminal Law and Philosophy, 8, 2014, hlm. 356-357 
pabrik tertentu tidak memiliki izin Usaha Perkebunan'. Dalam Pasal 8 Peraturan Menteri Pertanian Republik Indonesia Nomor: 29/Permentan/KB.410/5/2016 tentang Perubahan atas Peraturan Menteri Pertanian Nomor 98/Permentan/OT.140/9/2013 tentang Pedoman Perizinan Usaha Perkebunan bahwa yang dimaksud dengan luasan skala tertentu bagi usaha budi daya tanaman perkebunan adalah 25 (dua puluh lima) hektar atau lebih, sedangkan yang dimaksud dengan kapasitas pabrik tertentu berdasarkan Pasal 9 dan Lampiran II Peraturan Menteri tersebut sebagai berikut:51

Tabel 1.

Kapasitas Pabrik Perkebunan

\begin{tabular}{|c|c|c|c|}
\hline No & Komoditas & Kapasitas & Produk \\
\hline 1 & $\begin{array}{l}\text { Kelapa } \\
\text { Sawit }\end{array}$ & 5 ton TBS per jam & $\begin{array}{l}\text { CPO, inti sawit (palm kernel), } \\
\text { tandan kosong, cangkang, } \\
\text { serat (fiber), sludge }\end{array}$ \\
\hline ? & $T_{0}$ & 1 ton pucuk segar per hari & Teh Hijau \\
\hline 2 & lel & 10 ton pucuk segar per hari & Teh Hitam \\
\hline 3 & Tebu & 1000 ton tebu per hari & Gula Kristal Putih \\
\hline
\end{tabular}

Maksud larangan dalam Pasal 105 adalah untuk mencegah timbulnya kerusakan atau pencemaran lingkungan. Akan tetapi, mengapa hanya dibatasi pada usaha budi daya tanaman perkebunan dengan luasan skala tertentu atau usaha pengelolaan hasil perkebunan dengan kapasitas pabrik tertentu? Bila pemikiran ini diikuti, maka usaha budi daya tanaman perkebunan dengan luasan kurang dari 25 hektar atau di bawah kapasitas pabrik tertentu sesuai dengan Pasal 9 Peraturan Menteri di atas tidak berpotensi menimbulkan kerusakan atau pencemaran lingkungan sehingga hanya dikategorikan sebagai pelanggaran administrasi.

Selain itu, dalam Lampiran I Peraturan Menteri Negara Lingkungan Hidup Nomor 5 Tahun 2012 tentang Jenis Rencana Usaha Dan/Atau Kegiatan Yang Wajib Memiliki Analisis Mengenai Dampak Lingkungan Hidup, usaha budi daya tanaman perkebunan yang berdampak penting terhadap lingkungan hidup apabila luasnya; a) lebih dari 2.000 hektar untuk usaha budi daya tanaman perkebunan semusim dengan atau tanap unit pengelolaannya baik dalam kawasan budidaya

51 Pasal 9 berbunyi, "Usaha Industri Pengolahan Hasil Perkebunan kelapa sawit, teh dan tebu dengan kapasitas sama atau melebihi kapasitas paling rendah unit pengolahan hasil perkebunan seperti tercantum dalam Lampiran II yang merupakan bagian tidak terpisahkan dari Peraturan ini, wajib memiliki IUP-P”. 
non kehutanan maupun dalam kawasan hutan produksi yang dapat dikonversi; dan b) lebih dari 3.000 hektar untuk usaha budi daya tanaman perkebunan tahunan dengan atau tanpa unit pengelolaannya baik dalam kawasan budidaya non kehutanan maupun dalam kawasan hutan produksi yang dapat dikonversi.

Terakhir, beratnya pidana tidak mencerminkan keseriusan delik (disproportionate sentence) terdapat dalam Pasal 98 ayat (1) dan 112 yang merupakan delik materiil dibandingkan dengan Pasal 106 dan Pasal 107 UU PPLH yang dirumuskan sebagai delik formil. Ancaman pidanan terhadap delik formil justru lebih berat daripada delik materiil sebagaimana terlihat pada tabel di bawah ini:

Tabel 2.

Perbandingan Bobot Pidana antara Delik Materiil dan Delik Formil dalam UU PPLH

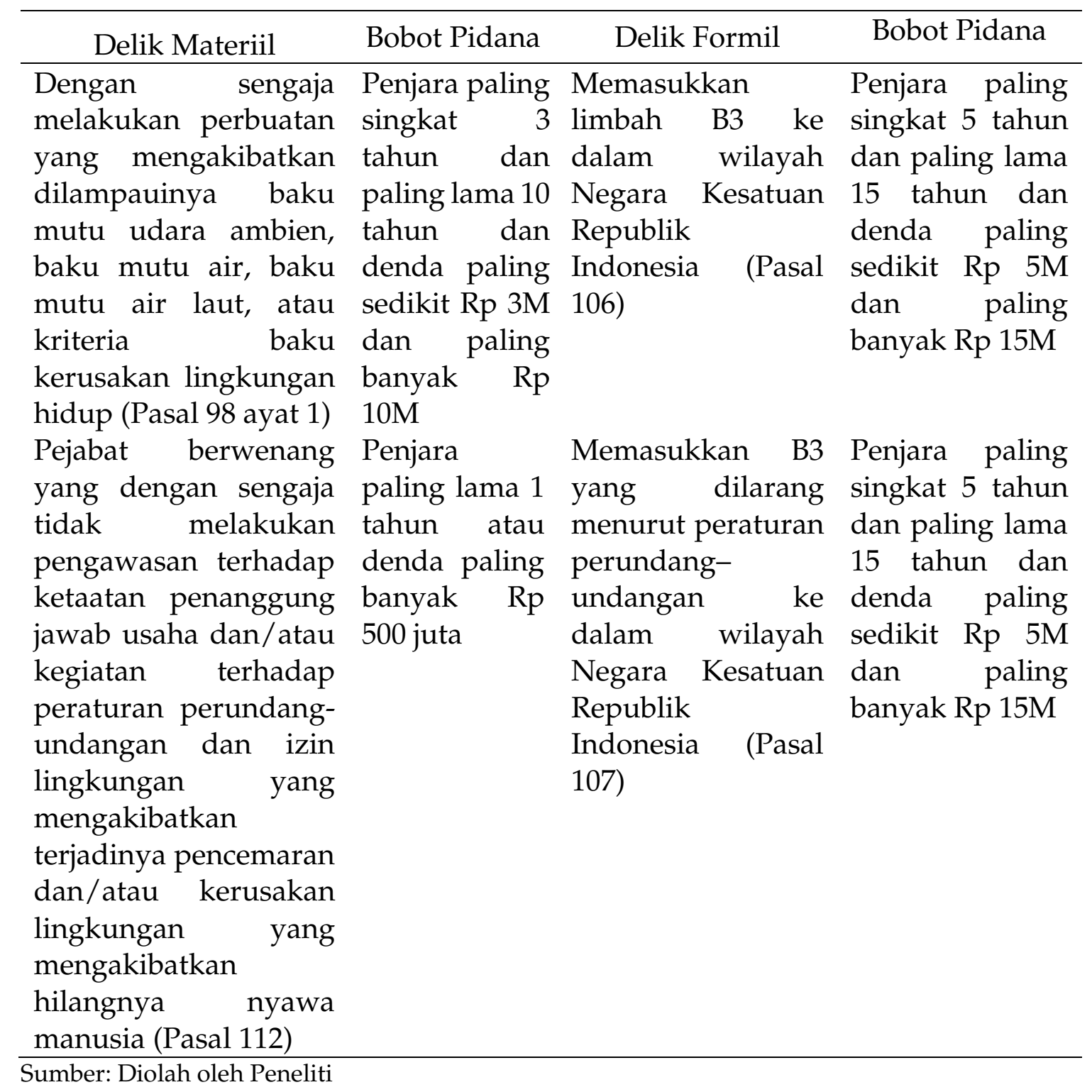


Berdasarkan tabel di atas, delik dalam Pasal 106 dan Pasal 107 merupakan delik formil, tapi ancaman pidananya justru lebih berat daripada delik materiil dalam Pasal 98 ayat (1), bahkan jauh lebih berat daripada Pasal 112. Perbuatan 'memasukkan limbah B3' atau memasukkan B3 yang dilarang menurut peraturan perundang-undangan' sekalipun berpotensi merusak dan/atau mencemarkan lingkungan, tapi potensi ini baru ada jika limbah B3 atau B3 dibuang ke media lingkungan. Unsur 'dibuang ke media lingkungan' bukan merupakan unsur delik dalam Pasal 106 dan Pasal 107 sehingga tidak logis bila ancaman pidana dalam kedua pasal (jauh) lebih berat daripada dalam Pasal 98 dan Pasal 112. Oleh karena itu, ancaman pidana dalam Pasal 106 dan Pasal 107 menimbulkan overpenalisasi bila dibandingkan dengan ancaman pidana dalam Pasal 98 apalagi mengacu kepada bobot pidana dalam Pasal 112. Hal ini karena delik dalam Pasal 98 dan Pasal 112 lebih serius dibandingkan delik dalam Pasal 106 dan Pasal 107.52

\section{Penutup}

Konsep overcriminalization secara umum mengacu kepada dua hal, yaitu overcriminalization dalam kaitannya dengan kriminalisasi (kebijakan formulasi/penegakan hukum in abstracto) dan overcriminalization dalam konteks penegakan hukum oleh aparat penegak hukum (kebijakan aplikasi/penegakan hukum in concreto). Bentuk-bentuk overcriminalization yang ditimbulkan dari kebijakan kriminalisasi meliputi rekriminalisasi suatu perbuatan yang telah dilarang oleh undang-undang yang lain, perumusan delik tanpa persyaratan kesalahan pelanggar yang memadai, kriminalisasi terhadap perbuatan perbuatan yang tidak tercela, perumusan delik yang tidak memenuhi prinsip lex certa, kriminalisasi terhadap pelanggaran administratif murni, ancaman pidana tidak sebanding dengan seriusitas delik, dan penegakan hukum pidana yang berlebihan oleh penegak hukum.

Overcriminalization dalam perundang-undangan juga beragam bentuknya. Pertama, overlappping crimes sebagaimana terlihat dalam Pasal 108 UU Perkebunan dan Pasal 108 UU PPLH. Kedua, delik yang tidak memenuhi prinsip lex certa yang dirumuskan dalam Pasal 162 jo Pasal 136 ayat (2) UU Minerba. Ketiga, kriminalisasi

${ }^{52}$ William W. Berry III, "Promulgating Proportionality”, Georgia Law Review, 69, 2011, hlm. 93-94 
terhadap pelanggaran administratif murni seperti dalam Pasal 105 UU Perkebunan. Keempat, ancaman pidana terhadap delik formil yang jauh lebih berat daripada delik materiil seperti tercantum dalam Pasal 106 dan Pasal 107 UU PPLH dibandingkan dengan ancaman pidana dalam Pasal 98 ayat (1) dan Pasal 112 UU PPLH.

\section{Daftar Pustaka}

\section{Buku}

Akbari, Anugerah Rizki, Potret Kriminalisasi Pasca Reformasi dan Urgensi Reklasifikasi Tindak Pidana di Indonesia, Institute for Criminal Justice Reform, Jakarta, 2015.

Arief, Barda Nawawi, Bunga Rampai Kebijakan Hukum Pidana,Cetk. Ketiga, Edisi Revisi, PT. Citra Aditya Bakti, Bandung, 2005.

Kapita Selekta Hukum Pidana, Cetk. Ketiga, PT. Citra Aditya Bakti, Bandung, 2013.

, Kebijakan Legislatif dalam Penanggulangan Kejahatan dengan Pidana Penjara, Cetk Ketiga, Badan Penerbit Universitas Diponegoro, Semarang, 2000. , Pembangunan Sistem Hukum Nasional (Indonesia), Cetk. Kedua, Pustaka Magister, Semarang, 2015.

Ibrahim, Johny, Teori dan Metodologi Penelitian Hukum Normatif, BayuMedia Publishing, Malang, 2006.

Muladi dan Barda Nawawi Arief, Teori-teori dan Kebijakan Hukum Pidana, Alumni, Bandung, 1998.

Kapita Selekta Sistem Peradilan Pidana, Badan Penerbit Universitas Dipenogoro, Semarang, 1995.

\section{Jurnal dan Makalah}

Adji, Indrianto Seno, Administratif Penal Law: Ke Arah Konstruksi Pidana Limitatif, Makalah Disampaikan pada Pelatihan Hukum dan Kriminologi oleh MAHUPIKI Bekerjasama dengan Fakultas Hukum UGM, Yogyakarta, 2327 Februari 2014.

Ashworth, Andrew, "Conception of Overcriminalization", Ohio State Journal of Criminal Law, 5, 2008.

Beale, Sara Sun, "The Many Faces of Overcriminalization: From Morals and Mattress Tags to Overfederalization", American University Law Review, 54, 2005

Brown, Darryl K., "Prosecutors and Overcriminalization: Thoughts on Political Dynamics and a Doctrinal Response", Ohio State Journal of Criminal Law, 6, 2009. 
Buck, Isaac D., "Enforcement Overdose: Health Care Fraud Regulation in an Era of Overcriminalization and Overtreatment", Maryland Law Review, 74, 2015.

Buell, Samuel W., “The Upside of Overbreadth”, New York University Law Review, $83,2008$.

Dervan, Lucian E., “White Collar Overcriminalization: Deterrence, Plea Bargaining, and the Loss of Innocence", Kentucky Law Journal, 2012-2013.

Haugh, Todd, “Overcriminalization's New Harm Paradigm”, Vanderbilt Law Review, 68, 2015.

, "Sox on Fish: A New Harm of Overcriminalization", Northwestern University Law Review, 109, 2015.

Husak, Douglas, "Crimes Outside the Core", Tulsa Law Review, 2004.

, "Social Engineering as an Infringement of the Presumption of Innocence: The Case of Corporate Criminality", Criminal Law and Philosophy, 8, 2014.

Overcriminalization The Limits of the Criminal Law, Oxford Unversity Press, New York, 2008.

, "Reasonable Risk Creation and Overinclusive Legislation", Buffalo Criminal Law Review, 1, 1998.

Jareborg, Nils, "Criminalization as Last Resort (Ultima Ratio)", Ohio State Journal of Criminal Law, 2005.

Jones, Gregory, "Over-Criminalization and the Need for a Crime Paradigm", Rutgers Law Review, 2014.

Jr., Paul J. Larkin, “A Mistake of Law Defense as a Remedy for Overcriminalization", Criminal Justice, 28, 2013.

Kadish, Sanford H., "The Crisis of Overcriminalization", American Criminal Law, 1968

Luna, Erik, "The Overcriminalization Phenomenon", American University Law Review, 2005.

Muladi, 'Proyeksi Hukum Pidana Materiil Indonesia di Masa Mendatang', Pidato Pengukuhan Guru Besar Ilmu Hukum Pidana, Fakultas Hukum Universitas Diponegoro, Semarang, 24 Februari, 1990.

Pierce, Michael, "The Court and Overcriminalization", Stanford Law Review Online, $68,2015$.

Podgor, Ellen S., "Overcriminalization: The Politics of Crime”, American University Law Review, 54, 2005.

Ramsay, Peter, “Overcriminalization as Vulnerable Citizenship", New Criminal Law Review, 13, 2010.

Raphael, Michal Buchhandler, "Overcriminalizing Speech", Cardozo Law Review, 2015 
Roger A. Fairfax, Jr., "From “Overcriminalization" to "Smart on Crime": American Criminal Justice Reform-Legacy and Prospects", Journal of Law, Economics E Policy, 7, 2011.

Schlegel, Kip., David Eitle, Steven Gunkel, "Are White-Collar Crimes Overcriminalized? Some Evidence on the Use of Criminal Sanctions against Securities Violators", Western State University Law Review, 2000-2001.

Smith, Stephen F., "Overcoming Overcriminalization”, Journal of Criminal Law and Criminology, 102, 2012.

Stuntz, William J., "Substance, Process, and the Civil-Criminal Line", Journal of Contemporary Legal Issues, 1996.

Supriadi, "Penetapan Tindak Pidana Sebagai Kejahatan dan Pelanggaran dalam Undang-undang Pidana Khusus", Mimbar Hukum, Vol 27, 3, 2015.

William W. Berry III, "Promulgating Proportionality", Georgia Law Review, 69, 2011.

\section{Undang-undang}

Undang-Undang No. 32 Tahun 2009 tentang Perlindungan dan Pengelolaan Lingkungan Hidup

Undang-Undang No. 39 Tahun 2014 tentang Perkebunan

Undang-Undang No. 4 Tahun 2009 tentang Pertambangan Mineral dan Batubara

Undang-Undang No. 8 Tahun 2010 tentang Pemberantasan Tindak Pidana Pencucian Uang 